\title{
EPIDEMIOLOGY OF OVERWEIGHT AND OBESITY OF TRAITORS OF THE MULTIMODAL FREIGHT MANAGEMENT OFFICE OF THE CITY PROVINCE OF KINSHASA
}

\author{
Kusuayi Mabele Godefroid, ${ }^{1}$ Nkiama Ekisawa Constant, ${ }^{1}$ Bongo Nzeloka Jolie, ${ }^{1}$ \\ Christophe Delecluse, ${ }^{2}$ Lepira Bompeka François ${ }^{3}$ \\ ${ }^{1}$ Kinesiology service, Physical Medicine and Rehabilitation, University of Kinshasa, \\ Republic Democratic of Congo \\ ${ }^{2}$ Faculty of movement and Rehabilitation sciences, Departement of movement science K.U. Leuven, Belgique \\ ${ }^{3}$ Nephrology service, Internal Medicine, University of Kinshasa, Republic Democratic of Congo
}

Primljen/Received 11. 11. 2018. god.

Abstract: Objective: To determine the prevalence of overweight and obesity in the workplace. Methods: We conducted a cross-sectional study with 210 workers of which 119 male $(56.7 \%)$ and 91 female (43.3\%) selected in a simple random manner in a company in the city of Kinshasa province between November 2013 to January 2014. Overweight was determined by workers with a body mass index between 25 and $29.9 \mathrm{~kg} / \mathrm{m}^{2}$ and obesity by those with a body mass index $\geq 30$ $\mathrm{kg} / \mathrm{m}^{2}$. Results: This study found a prevalence of $23.8 \%$ of overweight workers and $48.1 \%$ of workers suffering from obesity with predominance in women (65.5\% in men vs. $80.2 \%$ in women, $p<0.014)$. The frequency of risk factors associated with obesity increased with the increase in weight status of BMI ( $p<$ 0.001). Conclusion: Obesity is a common pathology in the workplace and hypertension is the main modifiable risk factor. Sedentarity is the main determinant of overweight and obesity. Obesity is a public health problem in the workplace in the city of Kinshasa because of the command and collaboration frameworks are most affected.

Key words: overweight, obesity, associated risk factors, work environment.

\section{INTRODUCTION}

In the history of mankind, physical activity was essential to the survival of the species because it was necessary for foraging. Until the first half of the nineteenth century, the main daily occupations of man were characterized by a great physical activity: hunting, earthwork, handicrafts, etc. The human being did not just
Prihvaćen/Accepted 04. 02. 2019. god.

survive, he progressed until the arrival of the automobile, television, video games and internet $(1,2)$.

Technical progress has especially reduced opportunities for physical activity in the workplace. It is a fact that many employees today spend most of their work time sitting in front of the computer or watching television $(3,4)$.

Physical inactivity and sedentary behavior are two different and independent dimensions of movement behavior, respectively associated favorably and unfavorably with health status $(5,6)$. The World Health Organization (WHO), based on observations from around the world, shows that physical inactivity is responsible for two million deaths each year. Death rates for non-communicable diseases increase with body mass and more significantly with obesity (body mass index z30) (6). According to the same organization, the burden of overweight and obesity is growing so rapidly in Africa that these pandemics have become a public health problem throughout the African region that deserves study (6). Obesity affects $30 \%$ of adults, or 44 million Mexicans, and 40\% are overweight (7). In 2002, China experienced a significant increase in obesity ( $2.6 \%$ of the population with a BMI $\geq 30$ ) and overweight in general $(14.7 \%$ of the population had a BMI $\geq$ 25), which affects about 215 million Chinese people (7). The 2008 figures confirmed the sharp rise in obesity in China: 90 million Chinese were obese and 200 million overweight. In the poorest countries, obesity is socially valued. For example, in Mauritania, girls of marriageable age are fattened to be more attractive and maximize their chances of finding a spouse. Unlike de- 
veloped countries, it is about affluent populations, and is therefore a sign of success and wealth. Obesity, a multifactorial disease, is now considered a pandemic characterized by a metabolic disorder resulting from an accumulation of excess fat in the body and whose consequences can be harmful to health. It is a progressive chronic disease. It constitutes a serious risk factor that compromises the psychosocial functioning and the quality of life of patients who suffer from it (7). The prevalence overweight and obesity among Kinshasa workers is not very well known. It is to fill this gap that the present study was undertaken in a Multimodal Transport company in the Democratic Republic of Congo, in this case the Office of Management of Multimodal Freight, OGEFREM in acronym.

\section{METHODS}

\section{Nature and period of study}

We opted for the descriptive method and conducted a cross-sectional study that determined the prevalence of overweight and obesity among workers during a period from $2^{\text {th }}$ November 2013 to $2^{\text {th }}$ January 2014.

\section{Framework of the study}

This study took place at the Office of Management of Multimodal Freight, OGEFREM in acronym, of the city of Kinshasa, Democratic Republic of Congo.

\section{Sample of the study}

Our target population consisted of 400 male and female workers, aged 18 and over regardless of their rank and function. Our study sample was 210 randomly selected workers including 119 male $(56.7 \%)$ and 91 (43.3\%) female employees. Inclusion criteria included having freely agreed to participate in study, being between 18 and 59 years of age, being in apparent good health and working in one of the company's directorates for at least one year of service. Excluded were any worker who did not meet the inclusion criteria above.

\section{Variables of the study}

The morphological variables, level of physical activity and physiology used were as follows:

- Size $(\mathrm{cm})$ : It was rated with a SECA brand toe in lightly clad workers, was measured standing, heeled joints, head positioned so that the line of sight is perpendicular to the body,

- Weight (kg): It was measured using a calibrated SEC dry weight scale in kilograms $(\mathrm{kg})$ to $100 \mathrm{~g}$ near him, the teenager stood on the scale, head up, looking towards the horizon with an undergarment. The body mass index (BMI) of workers was calculated using the following formula: BMI: mass ( $\mathrm{kg}$ )/height (m). According to the World Health Organization (WHO) and the International Working Group on Obesity $(8,9)$, overweight was defined for BMI values between 25 and $29.9 \mathrm{~kg} / \mathrm{m}^{2}$ and the obesity for the value greater than equal to $30 \mathrm{~kg} / \mathrm{m}^{2}$;

- Physical inactivity was measured by the number of steps per day $\leq 4999$ recorded using an OMERON pedometer (10). The quality of life was assessed by the "Medical Outcome Study Short Form 36" (MOS SF-36) or "Short Form 36" (SF-36) questionnaire, is a generic questionnaire, robust, reliable, acceptable for the long-term. term measurement of quality of life, and validated in French. It contains 36 questions addressed to 9 dimensions: physical abilities, limitations related to the physical state, breads, perceived health, then vitality, relational life, psychic health, and finally evolution of the health perceived. Each item is weighted to obtain a score between 0 (zero quality) and 100 (maximum quality) for each of the 9 dimensions. The first 4 dimensions can be summarized in a Physical Summary Score and the following 4 in a Psychic Summary Score (10). Excessive alcohol consumption is defined as 21 grams of alcohol per day (11);

- Hypertension (HTA) was defined as BP $\geq 140 / 90$ $\mathrm{mmHg}$ or the concept of antihypertensive therapy regardless of PA;

- Diabetes mellitus is defined as fasting blood glucose $\geq 126 \mathrm{mg} / \mathrm{dl}$ and dysglycemia or pre-diabetes (hyperglycemia or glycemic intolerance) with a blood glucose level of between $100 \mathrm{mg} / \mathrm{dl}$ and $125 \mathrm{mg} / \mathrm{dl}$ (11).

\section{Statistical analyzes}

The data collected was captured using Microsoft Excel 2013 Software and imported into the Social Science Statistical Package (SPSS) software version 21.0. Quantitative variables were presented as mean \pm standard deviation and their extremes in the tables. The comparison of proportions was made using the Chi square test. The statistics the test results used were interpreted at the level of significance $\mathrm{p} \leq 0.05$ for statistical decision making.

\section{Ethical consideration}

All workers had agreed to write for participation in the study according to the Helsinki Declarations. The information collected from the workers was kept confidential.

\section{RESULTS}

Socio-demographic characteristics workers are presented in Table 1. Of the 210 subjects in the study, 
Table 1. Socio-demographic and occupational characteristics of study subjects

\begin{tabular}{|c|c|c|}
\hline & $\mathrm{n}=210$ & $\%$ \\
\hline \multicolumn{3}{|l|}{ sex } \\
\hline Male & 119 & 56,7 \\
\hline Female & 91 & 43,3 \\
\hline \multicolumn{3}{|l|}{ Socio-professionnel level } \\
\hline Commanders & 89 & 42,4 \\
\hline Collaboration frameworks & 71 & 33,8 \\
\hline Executing agents & 50 & 23,8 \\
\hline Age ( $\mathrm{X} \pm$ and, extremes) & $45,1 \pm 8,9$ & $(27-59)$ \\
\hline $18-39$ years & 82 & 39 \\
\hline $40-59$ years & 128 & 61 \\
\hline \multicolumn{3}{|l|}{ Level of study } \\
\hline Superior & 173 & 82,4 \\
\hline Secondary & 18 & 8,6 \\
\hline Primary & 19 & 9 \\
\hline
\end{tabular}

there were 119 men (56.7\%) and 91 women (43\%), a sex ratio $\mathrm{H} / \mathrm{F}$ of 1.3. The most represented age group was over 40 years of age $(61.0 \%)$. The average age was $45 \pm 8.9$ years and the extremes at 27 and 59 years. Regarding the professional level, there were $89(42.4 \%)$, $71(33.8 \%)$ and $50(23.8 \%)$ executives. $173(82.4 \%)$ subjects studied had a higher level of education, 18 $(8.6 \%)$ at the secondary level and $19(9.0 \%)$ at the primary level.

The overall prevalence of overweight was $23.8 \%$ and obesity was $48.1 \%$. Overweight and obesity combined resulted in a prevalence of $71.9 \%$.

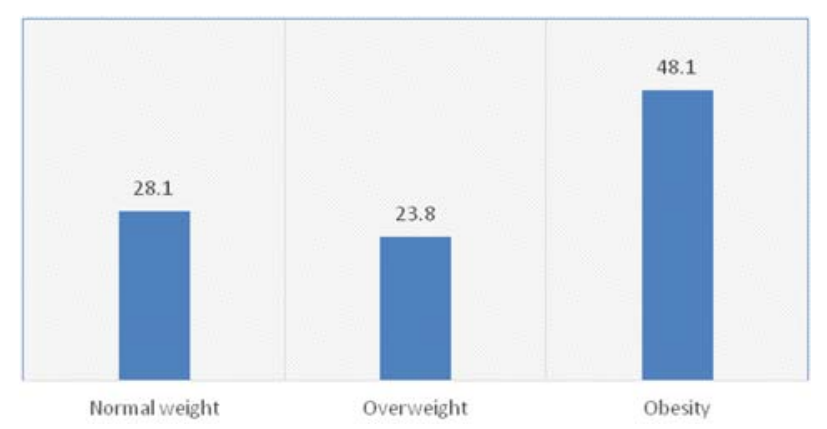

Figure 1. Overall frequency of overweight and obesity
According to sex, this prevalence is presented in Figure 2. When considering sex, Figure 2 shows that the specific prevalence is $80.2 \%$ for women and $65.5 \%$ for men. A statistically significant difference was found $(\mathrm{P}<0.014)$. Compared to men, women have a high frequency of overweight and obesity $(80.2 \%$ vs. $65.5 \%,(\mathrm{p}<0.014)$.

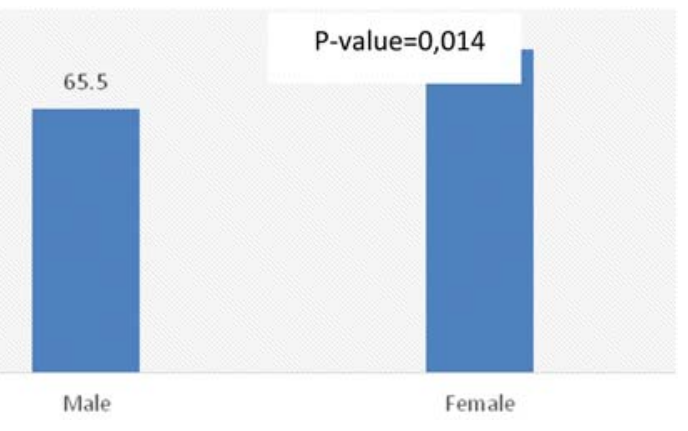

Figure 2. Frequency of overweight and obesity by sex

According to age, the frequency of overweight and obesity among the workers, Figure 3 shows us that workers aged 40 and over are most affected. The incidence of overweight and obesity increased significantly with age, so workers aged 40-59 were compared to those aged $18-39(76.6 \%)$. vs $64.6 \%, p=0.043)$.

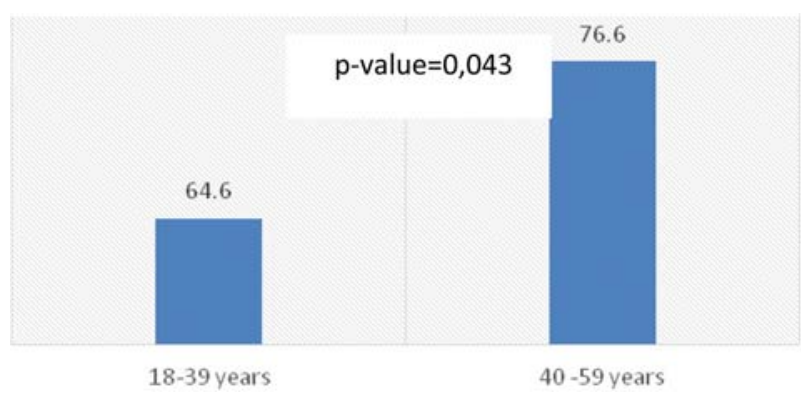

Figure 3. Frequency of overweight and obesity by age

Table 2 shows that the frequency of overweight and obesity increased significantly with high blood pressure $(p=0.0001)$ and the median daily energy expenditure was significantly higher among overweight workers than among workers obese 445 (111-1620) against 391 (118-1782).

Table 2. Frequency, median and mean associated risk factors by nutritional status

\begin{tabular}{|l|c|c|c|c|}
\hline & BMI & BMI & BMI & p-value \\
& $18,5 \mathrm{à} 24,9 \mathrm{Kg} / \mathrm{m}^{2}$ & $25 \mathrm{à} 29,9 \mathrm{Kg} / \mathrm{m}^{2}$ & $\geq 30 \mathrm{Kg} / \mathrm{m}^{2}$ & \\
\hline Hypertension n (\%) & $7(11,9)$ & $23(46,0)$ & $58(57,4)$ & 0,0001 \\
Diabetesmellitus n (\%) & $26(44,1)$ & $21(42,0)$ & $47(46,5)$ & 0,859 \\
Physical inactivity & $25(50,0)$ & $28(47,5)$ & $60(59,4)$ & 0,021 \\
Energy expenditure (Kcal) & $592(132-1782)$ & $445(111-1620)$ & $391(118-1782)$ & 0,007 \\
Number of steps per day & $5050(234-12738)$ & $4988(254-12738)$ & $4282(100-11530)$ & 0,003 \\
Time spent sitting (min/day) & $420(60-780)$ & $456(60-900)$ & $480(60-840)$ & 0,697 \\
\hline
\end{tabular}


Table 3. Determinants of overweight and obese in univaried and multivariate analysis

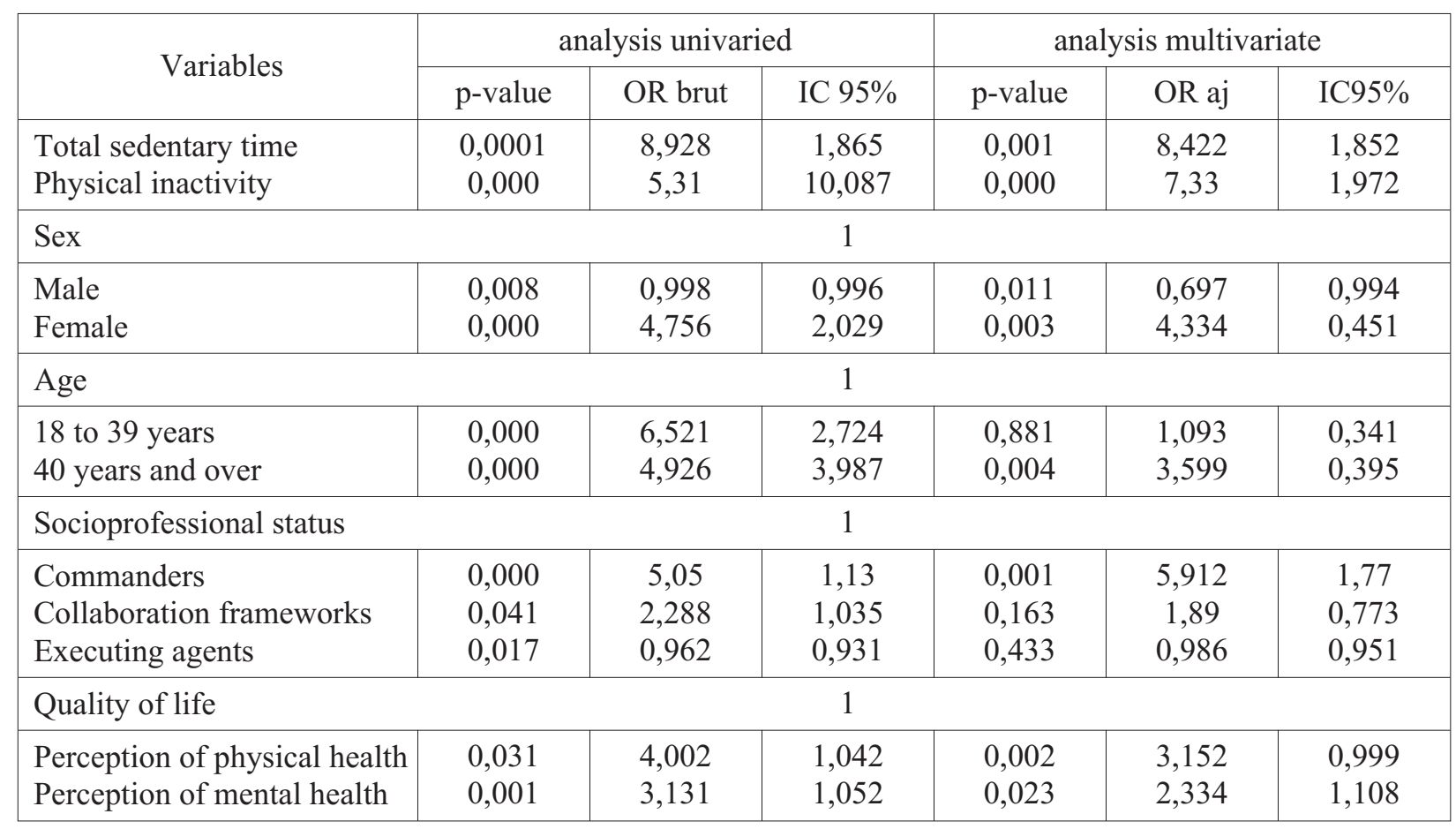

Table 3 identifies the determinants of overweight and obesity in univariate analyzes and multiple analyzes. In this regard, only the sedentary lifestyle expressed by the time spent sitting on the computer, physical inactivity, was the main determinant of overweight and obesity and increased the risk 8 times higher among sedentary employees.

\section{DISCUSSION}

This study aimed to determine the prevalence of overweight and obesity among workers in the city of Kinshasa. The prevalence of overweight and obesity among workers was $23.8 \%$ and $48.1 \%$, respectively. Women and people aged 40 and over were the most affected with an associated risk, unlike men. This result corresponds to those observed by Gennus, Silander and combine in the world of work (11). According to the latest WHO global estimates, $38 \%$ of men and $40 \%$ of women over 18 are obese. In the workplace, obesity is very worrying, Koffi and alliers found a prevalence of $38.1 \%$ among port authority workers, both in Cameroon, Etoundi and ally found $37 \%$ in hotels and 57\% observed by Fouda among shift workers working in the kitchen $(12,13,14)$. The more you are in command, the more you become sedentary and change your eating behavior. This finding is consistent with those of Bergman, Burton and Barnett and colleagues who have found that high socio-occupational status is closely linked to physical inactivity, poor eating behavior and sedentary lifestyles $(15,16)$. However, Gardiner, Gao,
Stamatakis and ally have shown that physical inactivity is related to an increase in nutritional status $(17,18$, 19). This study can not allow us to generalize our results to all companies in Kinshasa and other national entities. Nevertheless, they show the extent of a public health problem hitherto poorly known in the professional world of Kinshasa. This is an interesting prospect for further studies that will allow employers to reduce costs related to staff health care and optimize business productivity.

\section{CONCLUSION}

Obesity is a common pathology in the workplace and hypertension is the main modifiable risk factor. Physical inactivity was the main determinants of overweight and obesity. Obesity is a public health problem in the workplace in the city of Kinshasa because of the command and collaboration frameworks are most affected. Awareness and behavior change education interventions to prevent these risks.

\section{DECLARATION OF INTEREST}

The authors declare that there are no conflicts of interest.

\section{Licensing}

This work is licensed under a Creative Commons Attribution 4.0 International (CC BY 4.0) License. 


\title{
Sažetak
}

\section{EPIDEMIOLOGIJA PREKOMERNE TEŽINE I GOJAZNOSTI ČLANOVA MENADŽMENTSKE SLUŽBE GRADSKE PROVINCIJE KINŠASA}

\author{
Kusuayi Mabele Godefroid, ${ }^{1}$ Nkiama Ekisawa Constant, ${ }^{1}$ Bongo Nzeloka Jolie, \\ Christophe Delecluse, ${ }^{2}$ Lepira Bompeka François ${ }^{3}$

\footnotetext{
${ }^{1}$ Kinesiology service, Physical Medicine and Rehabilitation, University of Kinshasa, Republic Democratic of Congo

${ }^{2}$ Faculty of movement and Rehabilitation sciences, Departement of movement science K.U. Leuven, Belgique
} \\ ${ }^{3}$ Nephrology service, Internal Medicine, University of Kinshasa, Republic Democratic of Congo
}

Cilj: Utvrditi učestalost prekomerne težine i gojaznosti na radnom mestu. Metode: Sprovedena je unakrsna studija sa 210 nasumično odabranih radnika sa liste osoblja kompanije u gradu Kinshasa, u periodu od novembra 2013. do januara 2014. god., a koja je uključivala 119 muškaraca (56,7\%) i 91 ženu (43,3\%). Prekomerna težina je označena kod radnika sa BMI između 25 i $29.9 \mathrm{~kg} / \mathrm{m}^{2}$, a gojaznost kod onih kod kojih je BMI $\geq 30 \mathrm{~kg} / \mathrm{m}^{2}$. Rezultati: Rezultati studije pokazuju da je učestalost prekomerne težine kod radnika 23.8\%, dok $48.1 \%$ radnika pati od gojaznosti, i to sa većom

\section{REFERENCES}

1. Popkin BM., Doak CM. The obesity epidemic is a worldwide phenomenon. Nutr Rev. 1998; 56(4): 106-14.

2. James PT, Leach R, Kalamara E, Shayeghi M. The worldwide obesity epidemic. Obes Res. 2001; 9 (Suppl 4): 228-33.

3. Verdot C, Torres M, Salanave B, Deschamps V. Corpu- lence des enfants et des adultes en France metropolitaine en 2015. Résultats de l'étude Esteban et évolution depuis 2006. Bull Epidemiol Hebd. 2017; 13: 234-41.

4. Pedersen BK, Saltin B. Evidence for prescribing exercise as therapy in chronic disease. Scandinavian journal of medicine and science in sports. 2006; 16 (suppl. 1): 3-63.

5. Tudor L, Myers AM. Challenges and opportunities for measuring physical activity in sedentary adults. Sports Medicine. 2001; 31(2): 91-100.

6. Gaillard T, Schuster D, Osei K. Metabolic syndrome in Black people of the African diaspora: the paradox of current classification, definition and criteria. Ethn Dis. 2009; 19(suppl 2): 1-7.

7. Ozen KB., Sarac F, Sarac S, Uluer H, Yilmaz C. Metabolic Syndrome insulin resitance, fibrinogen, hemocysteine, leptin, and C-reative protein in obese patients with obstructive sleep apnea syndrome Annual Thoracic Medicine.2011; 6 (3): 120-5.

8. O’Donovan G, Thomas EL, McCarthy JP, Fitzpatrick J, Durighel G, Mehta S et al. Fat distribution in men of different waist girth, fitness level and exercise habit. Int J Obes (Lond). 2009; 33(12): 1356-62. učestalošću kod žena (65.5\% kod muškaraca naspram $80.2 \%$ kod žena, $\mathrm{p}<0.014)$. Učestalost faktora rizika povezanih sa gojaznošću raste sa porastom težine $\mathrm{i}$ BMI ( $p$ < 0.001). Zaključak: Gojaznost je česta na radnim mestima, a hipertenzija je glavni modifikujući faktor rizika. Sedentarni način rada je glavni uzrok prekomerne težine i gojaznosti. Gojaznost je problem javnog zdravlja na radnim mestima u Kinšasi, a najviše su pogođene rukovodeće službe.

Ključne reči: prekomerna telesna težina, gojaznost, pridruženi faktori rizika, radno okruženje.

9. Royer TD, Martin PE. Manipulations of leg mass and moment of inertia: effects on energy cost of walking. Med Sci Sports Exerc. 2005; 37(4): 649-56.

10. Mercuro G, Deidda M, Piras A, Dessalvi CC, Maffei S, Rosano GM, Gender. determinants of cardiovascular risk factors and diseases. J Cardiovas Med. 2010; 11(3): 207-20.

11. Gennus KP., Gangnon, CE. Matthews, KM., Thraen Borowski KM,Colbert LH. Sedentary behavior, physical activity, and markers of health in older adults. Med Sci Sports Exerc. 2013; 45(1): 1493-500.

12. Koffi NM, Sally SJ, Kouame P, Silue K, Nama AD. FaciPs de l'hypertension artérielle en milieu professionnel B Abidjan. Médecine d'Afrique Noire. 2001; 48(6): 257-60.

13. Ngoa L, Sego FM, Belinga A. Obesite en milieu hotelier: Influence du poste de travail sur les métabolismes lipidique et glucidique et sur la pression artérielle: de 180 employées de sexe féminin des Hôtels de Yaoundé au Cameroun. Médecine d'Afrique noire. 2006; 53(3): 137-41.

14. Fouda DB., Lemogoum J, Manga JO, Dissongo R. Tobbit DF, Moyo DF et al. Epidémiologie de l'obésité en milieu du travail B Douala au cameroun, Rev Méd Brux.. 2012; 33(3): 131-7.

15. Barnett TA., Gauvin L, Craig CL., Katzmarzy T. Distinct trajectories of leisure time physical activity and predictors of trajectory class membership: a 22 year cohort study. Int J Behav Nutr Phys Act. 2008; 5(1): 57-65.

16. Beunza JJ, Martinez Gonzales MA, Ebrahim S, Bes Rastrollo M, Nunez J, Martinez JA et al. Sedentary behaviors and the risk of incident hypertension: the SUN Cohort. Am J Hypertens. 2007; 20(11): 1156-62.

17. Helmerhorst HJ, Wijndaele K, Brage $\mathrm{S}$, Wareham $\mathrm{Nj}$, Ekelund U. Objectively measured sedentary time may predict 
insulin resistance independent of moderate- and vigorous intensity physical activity. Diabetes. 2009; 58(8): 1776-9.

18. Gao X, Nelson ME, Tucker KL. Television viewing is associated with prevalence of metabolic syndrome in Hispanic elders, Diabetes Care. 2007; 30(3): 694-700.
19. Stamatakis E, Davis M, Stathi A, Hamer M. Associations between multiple indicators of objectively-measured and self-reported sedentary behaviour and cardiometabolic risk in older adults. Preventive medicine. 2012; 54(1): 82-7.

\section{Correspondence to/Autor za korespondenciju}

\section{KUSUAYI MABELE Godefroid}

03 Thisuaka, Lemba Township, Kinshasa/RD, Congo

Kinesiology service, Department of Physical Medicine and Rehabilitation

Faculty of Medicine, University of Kinshasa, Democratic Republic of Congo

Email: kuswayi.mabele@unikin.ac.cd

phone number: +243810387310 